\title{
Investigating the Effect of Gypsum Powder on Chemical Constituents of Soil and Selected Crops, Adigudem, Tigray, Ethiopia
}

\section{Berhe Hailu and Samuel Estifanos*}

${ }^{1}$ School of Earth Sciences, CNCS, P.O. Box 231, Mekelle University, Mekelle, Ethiopia (*yidukabi@gmail.com).

\begin{abstract}
This paper investigates the effects of gypsum powder from the gypsum plant in Adigudem on chemical properties of soil as well as the yield of two major crops, wheat (Triticum aestivum) and barley (Hordeum vulgare). Three mixes of $10 \mathrm{~kg}$ of soil with $0 \%, 10 \%, 30 \%$, and $50 \%$ proportion of gypsum powder were used for pot experiments under glasshouse conditions at Mekelle University. One bulk soil sample was collected from a spot at $4 \mathrm{~km}$ from the eastern side of the plant. The chemical concentration of major elements $\mathrm{Ca}, \mathrm{K}, \mathrm{Na}, \mathrm{Mg}$, and $\mathrm{Mn}$, and trace elements, $\mathrm{Cd}, \mathrm{Zn}, \mathrm{Cu}, \mathrm{Pb}, \mathrm{Cr}$, and $\mathrm{Fe}$ in soil and plant parts were determined using an Atomic absorption spectrometer as well as $\mathrm{NO}_{3}, \mathrm{PO}_{4}$ and $\mathrm{SO}_{4}$ using UV-spectrometer. The results suggest that the gypsum powder enhances metals and anion content in soil and in crop parts compared to the control sample. The chemical constituents in soil and crop parts showed negligible variation with increasing proportions of gypsum powder. Gypsum loaded $\mathrm{Ca}, \mathrm{SO}_{4}$, $\mathrm{Mn}$, and $\mathrm{Pb}$ onto the soil, which exhibited higher $\mathrm{Mg}, \mathrm{Cu}, \mathrm{Mo}, \mathrm{Cd}, \mathrm{NO}_{3}$, and $\mathrm{PO}_{4}$ but the comparable concentrations of $\mathrm{Fe}, \mathrm{K}, \mathrm{Zn}$, and $\mathrm{Cr}$ in decreasing order. However, a direct relationship was noted in chemical constituent loadings along the pathway: powder-soil-crop in a similar fashion in the three mixes. Factor analyses revealed that wheat parts have a higher accumulation of nutrients than the barley parts with higher content in its growth soil blends. As an extension of this research, the in-situ investigation is recommended to assess the direct impact of the gypsum powder emitted over the soil and crops.
\end{abstract}

Keywords: Gypsum powder, Nutrients, Crop parts, Factor analysis, Tigray, Ethiopia.

\section{INTRODUCTION}

Sustainability of soil and crop production is a function of soil physical, chemical and biological properties. Small changes in these properties cause large impacts on crop growth and development, and thus crop yields. To maintain or improve soil properties for continuous longterm agricultural production, it is important to add inputs or soil amendments. Soil chemical characteristics are affected by soil amendments and the crop production system (Ekholm et al., 2012). Gypsum has been used as a soil amendment for a long time to provide $\mathrm{Ca}$ and $\mathrm{S}$ for plant nutrition, and this occurs any time gypsum is used as a soil amendment. Gypsum amendments significantly increased the growth and yield components of Wheat crop under soil salinity (Mamun et al., 2019). Other uses include remediating sodic soils by displacing $\mathrm{Na}$ with $\mathrm{Ca}$; ameliorating subsoil acidity by displacing $\mathrm{Al}^{3+}$ with $\mathrm{Ca}^{2+}$ followed by the $\mathrm{Al}^{3+}$ combining with Momona Ethiopian Journal of Science (MEJS),V13(1):164-176,2021 @CNCS, Mekelle University, ISSN:2220-184X Submitted on: $16^{\text {th }}$ January 2020 
$\mathrm{SO}_{4}{ }^{2-}$ from gypsum to form a less toxic entity; serving as an electrolyte source to promote rainwater infiltration and percolation and reduce soil swelling, dispersion, and crusting); and reducing water-soluble P coming off of fields (Mamedov et al., 2009; Marchesan et al., 2017). Gypsum application reduces the levels of $\mathrm{Al}^{3+}$ and $\mathrm{Mg}^{2+}$ and increased soil $\mathrm{pH}$, the levels of $\mathrm{Ca}^{2+}$, and ${\mathrm{S}-\mathrm{SO}_{4}}^{2-}$ (Leandro et al., 2014). The effect of gypsum on soil nature and Barley as well as Wheat has been studied by a number of researchers (Qadir et al., 2006; Elrashicl et al., 2010; Ekholm et al., 2012; Leandro et al., 2014; Vicensi et al., 2016; Khalil et al., 2017; Herrero et al., 2018). However; no studies were undertaken on gypsum dust particulate impacts on the growth of plants around gypsum factories in Tigray and elsewhere. This study, thus is critical to fill the information gap.

\section{METHODOLOGY}

\subsection{Study Area}

Adigudem is located at $30 \mathrm{~km}$ south of Mekelle city close to the Adigudem-Hiwane asphalt road in Hintalo-Wejerat Woreda (Fig 1). The Woreda lies between latitudes $12^{\circ} 55^{\prime} \mathrm{N}$ and $13^{\circ} 20^{\prime} \mathrm{N}$ and longitudes $39^{\circ} 20^{\prime} \mathrm{E}$ and $39^{\circ} 55^{\prime} \mathrm{E}$. The elevation of the area ranges from 1400 to $2850 \mathrm{~m}$ a.m.s.l. The relatively flat northern area around Adigudem forms part of the Mekelle Plateau. The Adi-Shoha Highlands to the south and west and Desa Escarpment to the east are characterized by rugged mountains and deeply incised valleys. Average annual rainfall is up to $850 \mathrm{~mm}$, decreasing to $300-400 \mathrm{~mm}$ in the east. Average temperature in the Woreda is about $180 \mathrm{C}$. However, in the highlands, the temperature drops upto $2-5^{\circ} \mathrm{C}$ during November to January (Gebrekidan and Samuel, 2011). Wind in the area is normally easterly for nine months of the year (September to May) and reverses its direction in the rainy season, June to August (Benjamin, 2005).

The Hintalo-Wejerat area is underlain by two main rock sequences within the Mekelle outlier (Bosellini et al., 1997). These are Jurassic to Cretaceous age sedimentary rocks comprised of sandstones, limestone and shale as well as Tertiary age volcanic basalts and dolerites. Recent alluvial deposits occur as fan deltas composed of black peaty cotton soils underlain by coarse grained conglomeratic alluvium especially where streams issue from the mountains into the valleys. Small plains underlain by such soils have developed within the broader valleys and flat areas upon Shale, such as in areas upstream of Mai Nebri and south of Adigudem. 


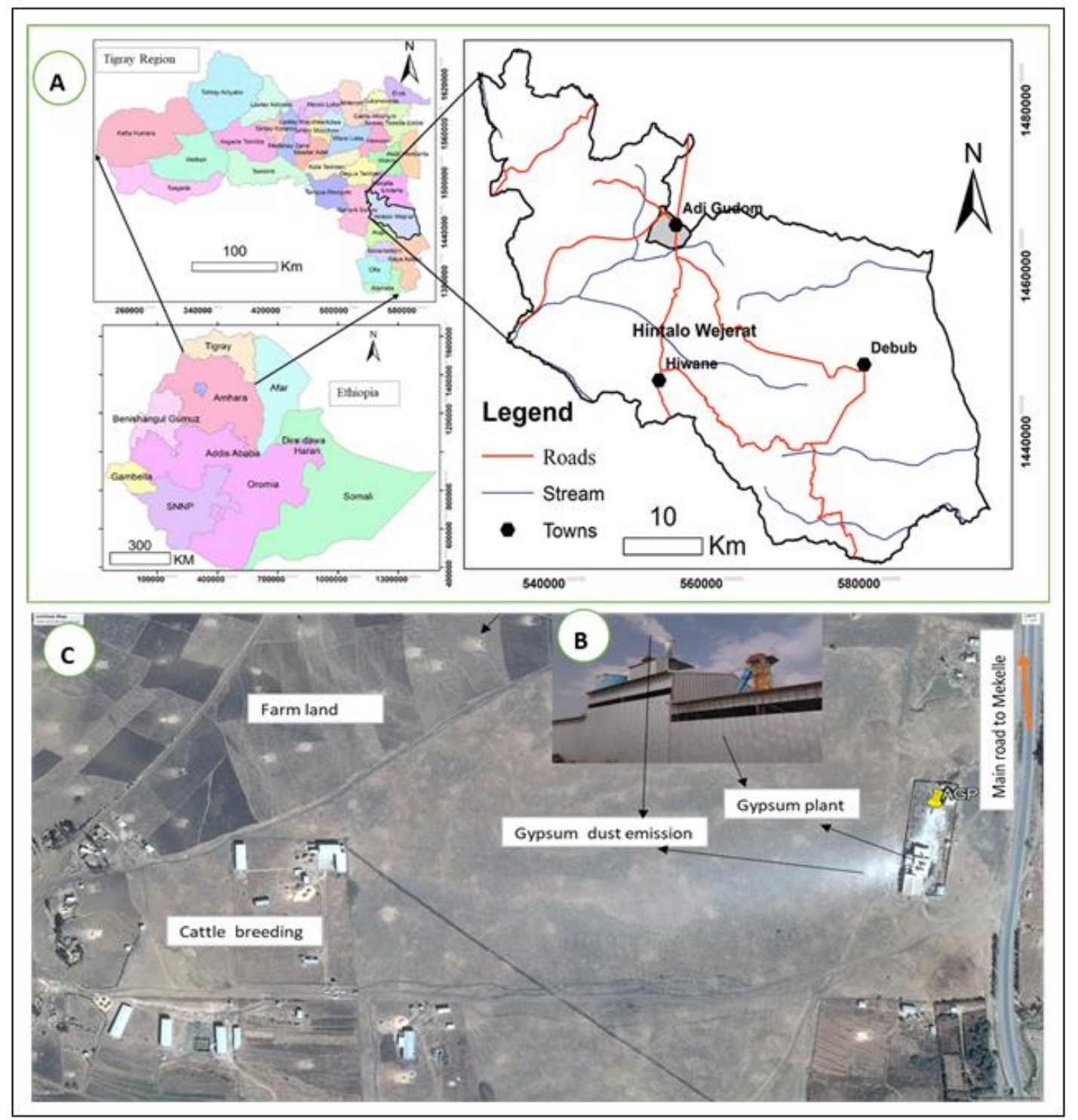

Figure 1. Location Map (A) with Gypsum plant near Adigudem (B) and its influence area (C).

\subsection{Soil Sampling and Crop Growth Experimental Set-up}

The overall steps taken in the experimental stage of the research are shown in figure 2. One bulk soil sample was collected from a spot on eastern side of Adigudem gypsum plant at 4km distance from undisturbed area at about $3 \mathrm{~km}$ distance from the study area where anthropogenic activities are minimal and are believed to represent geological background with reference to especially heavy metals. It was carefully taken from the top $10 \mathrm{~cm}$ soil part of a farm land not affected by gypsum dust emission. 
Crop growth experiment was conducted in $20 \mathrm{~cm}$ diameter and $25 \mathrm{~cm}$ deep plastic pots under glasshouse conditions accompanied by average temperature of $24^{\circ} \mathrm{C}$ and an average humidity of 45hygrometer. The pots were filled with soil and planted with wheat and barley. 24 plastic pots were filled each with $10 \mathrm{~kg}$ of soil mixed with $0 \%, 10 \%, 30 \%$ and $50 \%$ of gypsum power in three replications for each blend and used for germination and growth of both crops till maturity in 90days. Labels WS1, WS2, WS3 and WSc for wheat and BS1, BS2, BS3 and BSc for Barley denote decreasing gypsum powder proportions in the blends. The pots with mix of $0 \%$ gypsum (only soil) were used as control. The filled pots were left unsowed for one month to ensure top soil development so that nutrients are readily available for plant germination and growth. Mature and healthy seeds of Wheat (Triticum aestivum.) and barley (Hordeum vulgare L.) were procured from Mekelle University Agricultural research center. Six seeds of each crop were planted per pot and then thinned out to 3 plants soon after emergence according to Abate et al. (2013). All the seeds were sown by embedding about 3-4 cm depth into the soil and watering was done during evening with 1-liter per pot for the first 20 days and half-liter on subsequent days for 60 days. Watering of plants were done based on optimum humidity moisture level indicators.

\subsection{Physicochemical Analysis}

Physicochemical analysis was conducted for the soil sample (before used for crop growth and served as reference soil), water used for watering and gypsum powder obtained from the plant in geochemical laboratory at Mekelle University. Soil samples were taken from the 24-pots after 90days. Three sub-samples were prepared from each blend weighing one gram for analysis of major and trace elements/ Two samples, one gram each were prepared for each analysis to verify the precision of the Atomic Absorption Spectrometer (AAS) (Varian spectrometer AA50B, Flame AAS, Stand-alone system) whose detection limits are given in Appendix 1. One gram sample was mixed with $20 \mathrm{ml}$ aqua-regia stirring at $100^{\circ} \mathrm{C}$ for 20 minutes heated on a hot plate. Then $20 \mathrm{ml}$ of $0.1 \mathrm{~N} \mathrm{HCl}$ was added drop by drop to the digested samples and shake for 2 minutes. The resulting solution was filtered by adding distilled water until the filtrate gets $50 \mathrm{ml}$ volume before cation and major and minor elements measurements were done. For sulphate analysis, $2.5 \mathrm{ml}$ of each filtrate was mixed with 2drops of reagent $\mathrm{SO}_{4}-1$ and 1 level micro-spoon of reagent $\mathrm{SO}_{4}-2$; heated up to $40^{\circ} \mathrm{C}$ in water bath for 5 minutes and shacked occasionally. Then $2.5 \mathrm{ml}$ of reagent $\mathrm{SO}_{4}-3$ was added into each sample with pipette and mixed thoroughly. 4 drops 
of reagent $\mathrm{SO}_{4}-4$ were added into the filtrate of each sample and heated up to $40^{\circ} \mathrm{C}$ for 7 minutes and shacken occasionally. $10 \mathrm{~mm}$ of each sample was filled in a cell and sulphate concentration was measured in the UV photometer. For nitrate analysis, $50 \mathrm{mg}$ of amidosulfonic acid was added to each $5 \mathrm{ml}$ of the filtrate and dissolve by maintaining $\mathrm{pH}$ within 1-3 range. Then, 1 micro-spoon of reagent $\mathrm{NO}_{3}-1$ and $5 \mathrm{ml}$ of reagent $\mathrm{NO}_{3}-2$ was added and shaken vigorously for 1 minute until reagent $\mathrm{NO}_{3}-1$ is completely dissolved. $1.5 \mathrm{ml}$ of the solution of each sample was taken and waited for 10 minutes reaction time before analyzing the nitrate values of the samples in the UV. For phosphate analysis, $5 \mathrm{ml}$ of each original sample was mixed with $1.2 \mathrm{ml}$ of reagent $\mathrm{PO}_{4}-1$. The solution of each sample was filled into $10 \mathrm{~mm}$ cell and put into UV photometer for measurement.

\subsection{Plant Tissue Chemical Analysis}

Wheat and barley were treated to assess the accumulation of metals from soil under gypsum dust impact. The seeds were investigated separately to examine the storability of the toxic heavy metals in the edible and non-edible parts of the crops. The seed as well as composite of root and shoot parts were prepared from all batches. These were dried in stove at $100^{\circ} \mathrm{C}$ for 48 hours and were ground using electrical and manual grinder. To ensure homogenization and same particle size, the ground crop parts were sieved using $0.25 \mathrm{~mm}$ net sieve. $0.5 \mathrm{~g}$ of each ground samples were digested with $5 \mathrm{ml}$ of nitric acid and $3 \mathrm{ml}$ of hydrogen peroxide at $160^{\circ} \mathrm{C}$ for $1 \mathrm{hr}$. Then the digested 48 plants samples were analyzed in geochemical laboratory of Mekelle University using AAS and sulfate content was determined using UV photometer. Root and shoot fresh parts were weighed with analytical balance in Mekelle university botanical laboratory before and after drying at $80-105^{\circ} \mathrm{C}$. Precautions were taken to avoid contaminations during the sample preparation and laboratory analysis. Variation in the measurements by the AAS is below $10 \%$.

\subsection{Data Analysis Techniques}

Comparisons were made between the chemical constitutes of control (soil-only, gypsum-powderonly and water only) and blended groups. Similarly, comparison was made for soil chemical parameters between control and treatment groups. The chemical analysis data are presented with descriptive statistics using marker lines and histograms of Microsoft spread sheet. Both physicochemical parameters were analyzed through Microsoft Excel. Factor analysis and oneway ANOVA was conducted for all dataset in order to understand the prevailing associations of the physicochemical parameters using SPSS version 26.0. In factor analysis, Principal 
Component Analysis and Varimax with Kaiser Normalization were used where Rotation converged in 5 iterations producing four factors.

Figure 2. Flow chart summarizing the procedure.

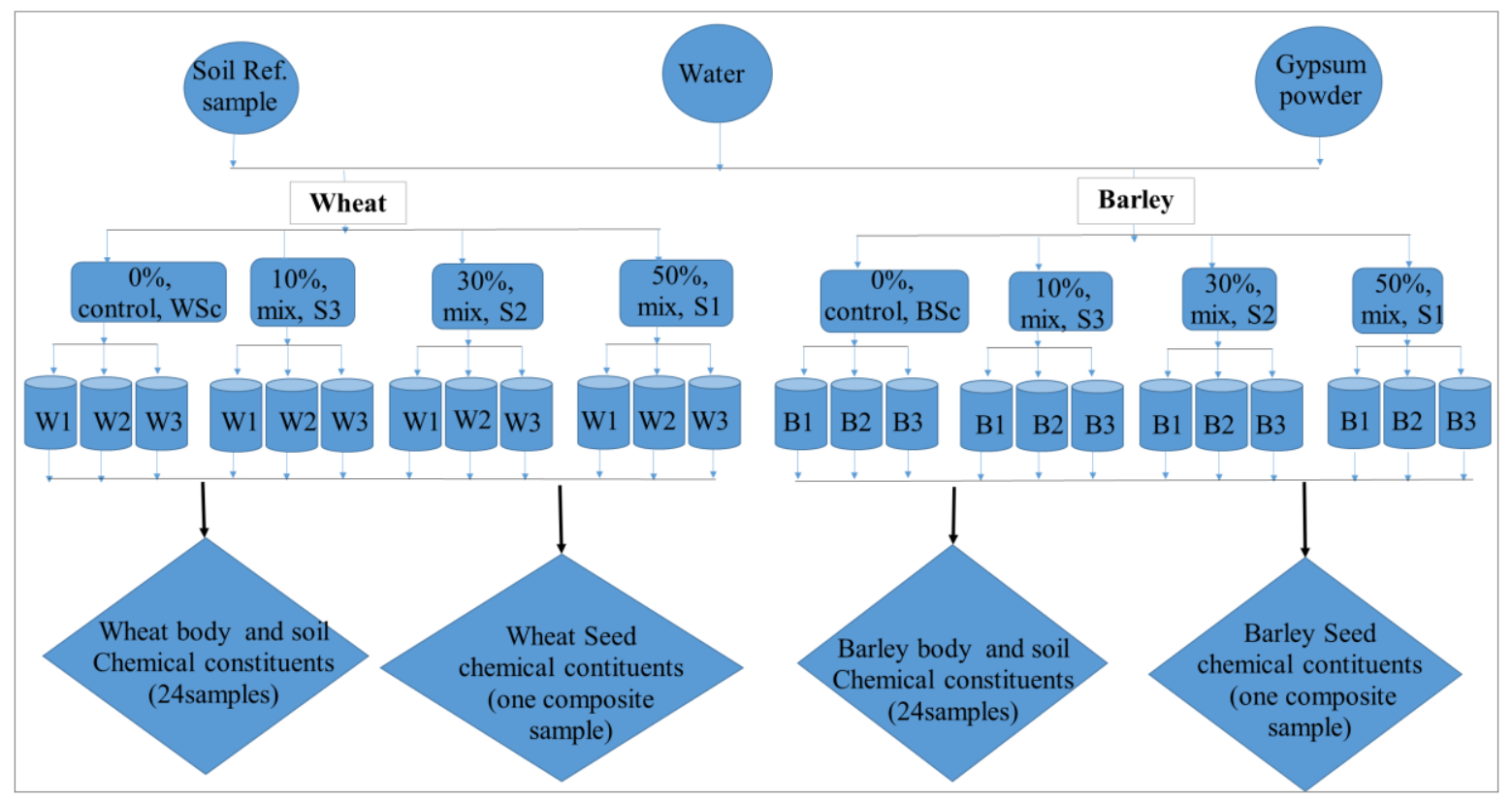

\section{RESULTS AND DISCUSSION}

\subsection{Effect of Gypsum on Soil constituents}

The result of chemical analysis for major, trace and anions constituents determined from the four levels of soil-gypsum mixes, gypsum powder and water used for watering the crops are presented in table 1 and figure 3. The major elements whose concentration generally increases from control (only soil) to the soil- gypsum mix are $\mathrm{Mn}, \mathrm{Na}, \mathrm{K}, \mathrm{Fe}, \mathrm{Mg}$ and $\mathrm{Ca}$. All the parameters except copper do not show significant variation in the three levels of blends in the pots used for wheat growth (WS1, WS2 and WS3). In the case of barley, all except $\mathrm{K}, \mathrm{Ca}, \mathrm{Mg}, \mathrm{Fe}$, $\mathrm{Pb}, \mathrm{SO}_{4}$ and $\mathrm{PO}_{4}$ increases with increase of gypsum proportion. Comparing with the control soil sample, the blended soil used for wheat growth shows higher content of all trace elements except $\mathrm{Mn}, \mathrm{Cr}$ and $\mathrm{Pb}$, while all but $\mathrm{Mn}$ in the case of barley including anions $\mathrm{SO}_{4}, \mathrm{PO}_{4}$ and $\mathrm{NO}_{3}$. The gypsum powder has higher $\mathrm{Na}, \mathrm{Ca}, \mathrm{Fe}, \mathrm{Mn}$ and $\mathrm{SO}_{4}$ and lesser $\mathrm{Mg}, \mathrm{NO}_{3}$ and $\mathrm{PO}_{4}$ than all soil blends of both crops.

Table 1. Cations and anions concentrations in crop body, gypsum powder and water (ppm) with standard deviation (Note: WS-soil for wheat; BS-soil for barley growth).

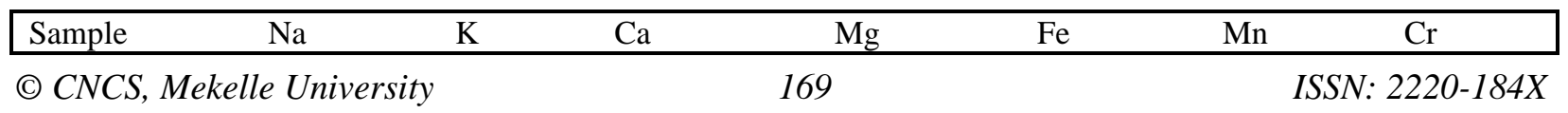




\begin{tabular}{|c|c|c|c|c|c|c|c|c|}
\hline Gypsum Powder & $164.0 \pm 9.1$ & $6.7 \pm 0.2$ & \multicolumn{2}{|c|}{$20261.0 \pm 250$} & $1148.0 \pm 85$ & $646.0 \pm 42$ & $2.9 \pm 0.11$ & $0.07 \pm 0.0$ \\
\hline Ref. Soil & $140.33 \pm 7.5$ & \multirow{2}{*}{$\frac{3.13 \pm 0.1}{5.6+0.5}$} & \multicolumn{2}{|c|}{$4853.3 \pm 130$} & $3820.0 \pm 137$ & $1430.0 \pm 52$ & $1.4 \pm+0.04$ & $0.17 \pm 0.0$ \\
\hline WS1 & $164.0 \pm 8.9$ & & \multicolumn{2}{|c|}{$6450.0 \pm 180$} & $2400.0 \pm 110$ & $564.0 \pm 22$ & $1.7 \pm 0.01$ & $0.08 \pm 0.0$ \\
\hline WS2 & $166.0 \pm 8.5$ & $5.6 \pm 0.4$ & \multicolumn{2}{|c|}{$6452.0 \pm 175$} & $2403.0 \pm 121$ & $562.0 \pm 25$ & $1.7 \pm 0.01$ & $0.09 \pm 0.0$ \\
\hline WS3 & $164.0 \pm 8.7$ & $5.6 \pm 0.5$ & \multicolumn{2}{|c|}{$6451.0 \pm 185$} & $2404.0 \pm 114$ & $561.0 \pm 21$ & $1.6 \pm 0.01$ & $0.08 \pm 0.0$ \\
\hline WSc & $143.0 \pm 7.1$ & $6.5 \pm 0.4$ & \multicolumn{2}{|c|}{$4512.0 \pm 154$} & $3203.0 \pm 128$ & $611.0 \pm 29$ & $1.4 \pm 0.1$ & $0.05 \pm 0.0$ \\
\hline$\overline{B S 1}$ & $159.0 \pm 8.4$ & $6.5 \pm 0.4$ & \multicolumn{2}{|c|}{$6486.0 \pm 189$} & $2501.0 \pm 125$ & $587.0 \pm 26$ & $2.1 \pm 0.2$ & $0.04 \pm 0.0$ \\
\hline $\mathrm{BS} 2$ & $156.0 \pm 8.2$ & $6.3 \pm 0.5$ & \multicolumn{2}{|c|}{$6482.0 \pm 187$} & $2495.0 \pm 118$ & $583.0 \pm 28$ & $2 \pm 0.2$ & $0.03 \pm 0.0$ \\
\hline$\overline{B S 3}$ & $149.0 \pm 8.0$ & $6.1 \pm 0.3$ & \multicolumn{2}{|c|}{$6478.0 \pm 174$} & $2493.0 \pm 117$ & $579.0 \pm 19$ & $1.8 \pm 0.9$ & $0.01 \pm 0.0$ \\
\hline $\mathrm{BSc}$ & $139.0 \pm 5.5$ & $6.7 \pm 0.6$ & \multicolumn{2}{|c|}{$4518.0 \pm 153$} & $3345.0 \pm 130$ & $628.0 \pm 40$ & $1.6 \pm 0.8$ & $0.07 \pm 0.0$ \\
\hline Water & $32.0+1.2$ & $0.9 \pm 0.01$ & \multicolumn{2}{|c|}{$322.3 \pm 35$} & $23.7 \pm 1.0$ & $0.9 \pm 0.02$ & $1.9 \pm 1$ & $0.07 \pm 0.0$ \\
\hline Sample & $\mathrm{Cu}$ & $\mathrm{Pb}$ & $\mathrm{Zn}$ & Mo & $\mathrm{Cd}$ & $\mathrm{NO}_{3}$ & $\mathrm{PO}_{4}$ & $\mathrm{SO}_{4}$ \\
\hline Gypsum Powder & $18 \pm 1.3$ & $0.5 \pm 0.0$ & $4.1 \pm 0.1$ & $0.6 \pm 0.0$ & $0.1 \pm 0.0$ & $44.3 \pm 1.9$ & $4.6 \pm 0.1$ & $18654.0 \pm 230$ \\
\hline Ref. Soil & $12.8 \pm 2$ & $0.5 \pm 0.0$ & $4.6 \pm 0.5$ & $2.4 \pm 0.2$ & $0.6 \pm 0.0$ & $27.4 \pm 2.3$ & $1.4 \pm 0.1$ & $271.8 \pm 32$ \\
\hline WS1 & $18 \pm 1.5$ & $0.7 \pm 0.0$ & $3.3 \pm 0.1$ & $0.6 \pm 0.0$ & $0.3 \pm 0.0$ & $46.8 \pm 2.0$ & $6.3 \pm 0.2$ & $301.0 \pm 11$ \\
\hline WS2 & $17 \pm 2.1$ & $0.7 \pm 0.0$ & $3.2 \pm 0.2$ & $0.6 \pm 0.0$ & $0.3 \pm 0.0$ & $46.7 \pm 2.1$ & $6.2 \pm 0.4$ & $302.0 \pm 12$ \\
\hline WS3 & $16 \pm 1.9$ & $0.7 \pm 0.0$ & $3.2 \pm 0.4$ & $0.7 \pm 0.0$ & $0.3 \pm 0.0$ & $46.8 \pm 1.6$ & $6.2 \pm 0.3$ & $301.0 \pm 11$ \\
\hline WSc & $19 \pm 2.2$ & $0.1 \pm 0.0$ & $4.1 \pm 0.5$ & $1.0 \pm 0.01$ & $0.5 \pm 0.0$ & $52.4 \pm 2.2$ & $8.4 \pm 0.8$ & $292.0 \pm 14$ \\
\hline BS1 & $18 \pm 1.8$ & $0.1 \pm 0.0$ & $4.3 \pm 0.4$ & $1.0 \pm 0.01$ & $0.4 \pm 0.0$ & $55.0 \pm 2.2$ & $8 \pm 0.7$ & $331.0 \pm 19$ \\
\hline BS2 & $17.2 \pm 1.2$ & $0.1 \pm 0.0$ & $4.2 \pm 0.5$ & $1.0 \pm 0.01$ & $0.4 \pm 0.0$ & $53.9 \pm 2.4$ & $7.9 \pm 0.7$ & $329.0 \pm 16$ \\
\hline $\mathrm{BS} 3$ & $17.1 \pm 1.4$ & $0.7 \pm 0.0$ & $3.9 \pm 0.3$ & $0.9 \pm 0.01$ & $0.3 \pm 0.0$ & $52.6 \pm 2.2$ & $8 \pm 0.7$ & $326.0 \pm 15$ \\
\hline $\mathrm{BSc}$ & $21 \pm 2.1$ & $0.1 \pm 0.0$ & $4.2 \pm 0.3$ & $1.1 \pm 0.01$ & $0.5 \pm 0.0$ & $57.0 \pm 2.1$ & $9 \pm 0.8$ & $333.0 \pm 12$ \\
\hline Water & $19 \pm 2.2$ & $0.3 \pm 0.0$ & $4 \pm 0.3$ & $0.7 \pm 0.01$ & $0.3 \pm 0.0$ & $42.0 \pm 1.4$ & $6.1 \pm 0.6$ & $144.3 \pm 7.2$ \\
\hline
\end{tabular}
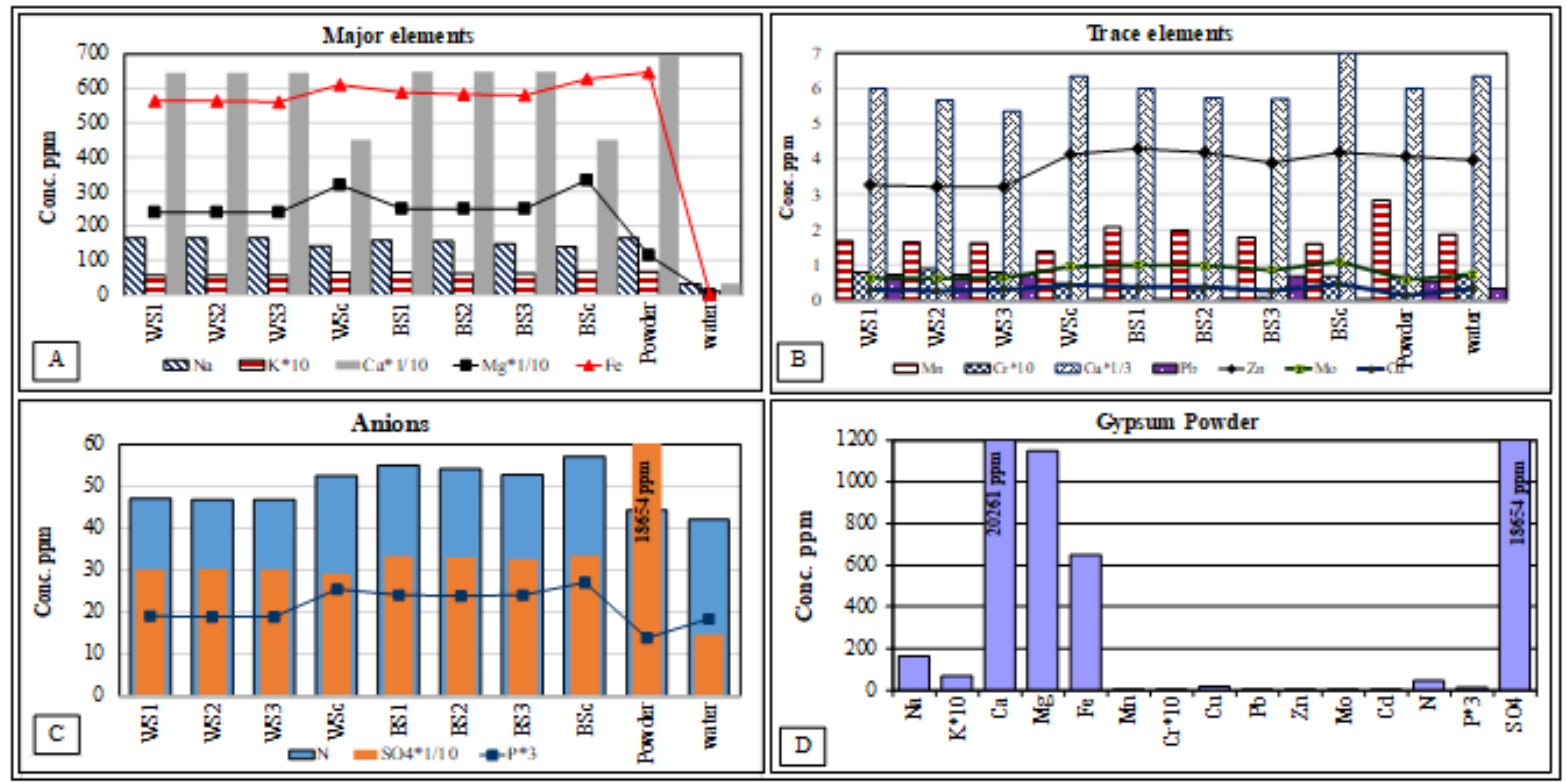

Figure 3. Chemical constituents of soil, gypsum and water (Note: Some parameters are multiplied by some factors to enhance their depiction on the graphs and $\mathrm{N}-\mathrm{NO}_{3} \& \mathrm{P}-$ $\left.\mathrm{PO}_{4}\right)$. 
However, it is found to have comparable content of $\mathrm{K}, \mathrm{Cr}$, and $\mathrm{Pb}$, with control soil of both crops. The reference soil has more $\mathrm{Mg}, \mathrm{Fe}, \mathrm{Zn}, \mathrm{Mo}$ and $\mathrm{Cd}$ than gypsum powder. The soil blends of barley show generally higher concentrations of all trace metals and anions except $\mathrm{Cr}$ and $\mathrm{Pb}$ as compared to that of wheat though both have comparable values of $\mathrm{Ca}$ and $\mathrm{Mg}$.

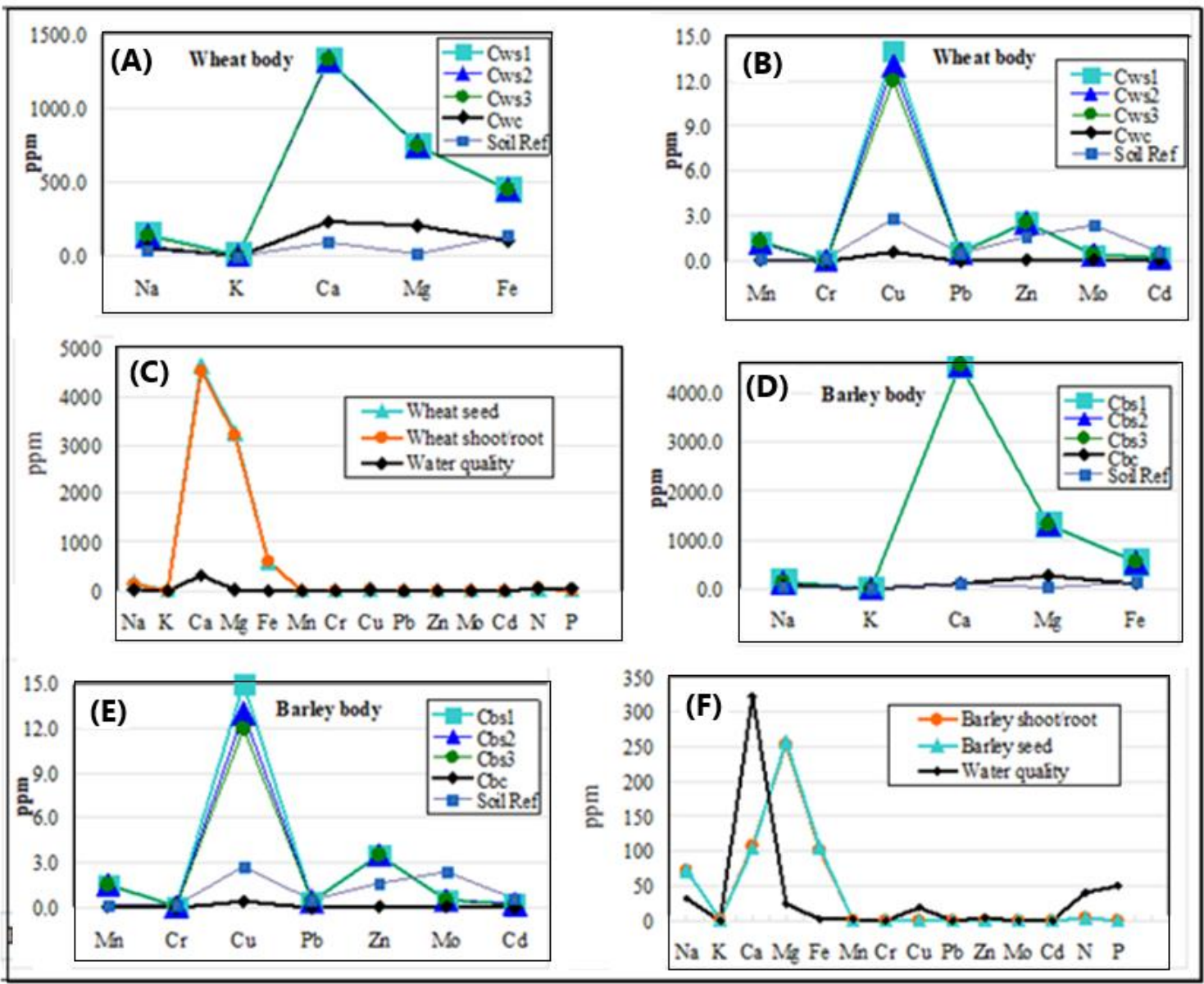

Figure 4. Chemical constituents in Wheat (A-C) and Barley (D-F) parts with Reference Soil.

The chemical characteristics of soil-gypsum mix used to grow both crops and composition of gypsum are presented in figure 4. Figure 4B shows that Barley soil blends have higher trace metals accumulation that might imply the resistance of Barley crops to uptake the metals. Similar is true for the anions, $\mathrm{NO}_{3}, \mathrm{PO}_{4}$ and $\mathrm{SO}_{4}$ (Fig $4 \mathrm{C}$ ). The soil blend of both crops is found to have more $\mathrm{Mg}, \mathrm{Mo}, \mathrm{Cd}, \mathrm{NO}_{3}$ and $\mathrm{PO}_{4}$ content than the gypsum powder (Kost et al., 2018). Matula and Pechová (2007) pointed out that the insignificant variation in the main cation nutrients $(\mathrm{Na}, \mathrm{K}, \mathrm{Ca}, \mathrm{Mg}$ and $\mathrm{Fe}$ ) can be assumed that the impact of the gypsum treatment on their uptake was mainly influenced by the establishment of equilibrium between the sorption (C) CNCS, Mekelle University 
complex of soils and the liquid phase of soils after a radical supply of calcium to soils through the gypsum dose. Gypsum is known to affect $\mathrm{Mg}$ concentrations in soil and this is reflected in the difference between control blend and the other blends in both crops due to the replacement of $\mathrm{Mg}$ by $\mathrm{Ca}$ in the soil, thus mobilizing the $\mathrm{Mg}$ and allowing it to move into the interstitial soil water (Kost et al., 2018).

\subsection{Effect of Gypsum Dust on Nutrient Intake of Crops}

The mean concentration of the elements in the crop body and seed are presented in figure 4. Among the major ( $\mathrm{Na}, \mathrm{K}, \mathrm{Ca}, \mathrm{Mg}$, and $\mathrm{Fe}$ ) and trace elements $(\mathrm{Cr}, \mathrm{Cu}, \mathrm{Pb}, \mathrm{Zn}, \mathrm{Mo}, \mathrm{Cd})$, the major elements show higher concentration in both the crops as well as soil and dust samples than the trace elements. Calcium remains highest in the crops and it is the second abundant next to magnesium in soil/powder samples. Calcium has the highest concentration of $4561 \mathrm{ppm}$ (45.91\%) in soil samples and also shows maximum in barley among the crops (Kost et al., 2018). The major metals in barley seed and body (shoot and root) samples showed even distribution over the soil blends.

Potassium, sodium and nitrogen did show preferential increment with slight variation in calcium. Unlike wheat, $\mathrm{Mg}, \mathrm{Fe}$ and $\mathrm{Mn}$ in barley showed slight decrement in crops growth with soil from crop growth-1 (Cbs1) up to crop growth-3 (Cbs3) (Fig 4D). The macronutrients: Mg and $\mathrm{Ca}$ in barley crop parts show clear increment in seeds harvested in crop growth-1 (Cbs1) up to crop growth-2 (Cbs2) relative to control (Cbc) (Fig 4D).

The major elements (major nutrients): $\mathrm{Na}, \mathrm{K}, \mathrm{Ca}$ and $\mathrm{Mg}$ are highly mobile, bioavailable and easily transferable from soil to plant systems (Rodriguez and Rubio, 2006). This natural phenomenon was evident in this study that the accumulation of nutrients in root and shoot of wheat is related with the increasing concentration of $\mathrm{Na}$ in soil. The highest and lowest concentrations of $\mathrm{Na}$ in root and shoot were found in control (78 $\mathrm{mg} \mathrm{kg}-\mathrm{l})$ and crop growth (145 mg kg-l).

Figure 5 illustrate the relative proportion the nutrients intake by crops in their seeds and shoot/root compared to water quality. The major metals in wheat seed and body (shoot and root) samples showed even distribution over the soil samples growth pots. Potassium, sodium and calcium did not show any preferential Increment or decrement in the experiment. On the contrary, Mg, Fe and Manganese slight increment in crops grown with soil from crop growthlup to crop growth-3 compared to those grown in soil from control crop growth). Regarding the 
trace elements in wheat crop parts, $\mathrm{Pb}$ (from 0 to $0.105 \mathrm{ppm}$ ) and Mo (from 0 to $0.95 \mathrm{ppm}$ ) show increment in wheat seed grown in S-1 up to S-3. Chromium and cadmium also had increasing trends with distance. In both the seeds and body of wheat crop, $\mathrm{Zn} \mathrm{Pb}, \mathrm{Mo}, \mathrm{Cd}, \mathrm{NO}_{3}, \mathrm{PO}_{4}$ and $\mathrm{Cu}$ showed a general decreasing trend the experiment.

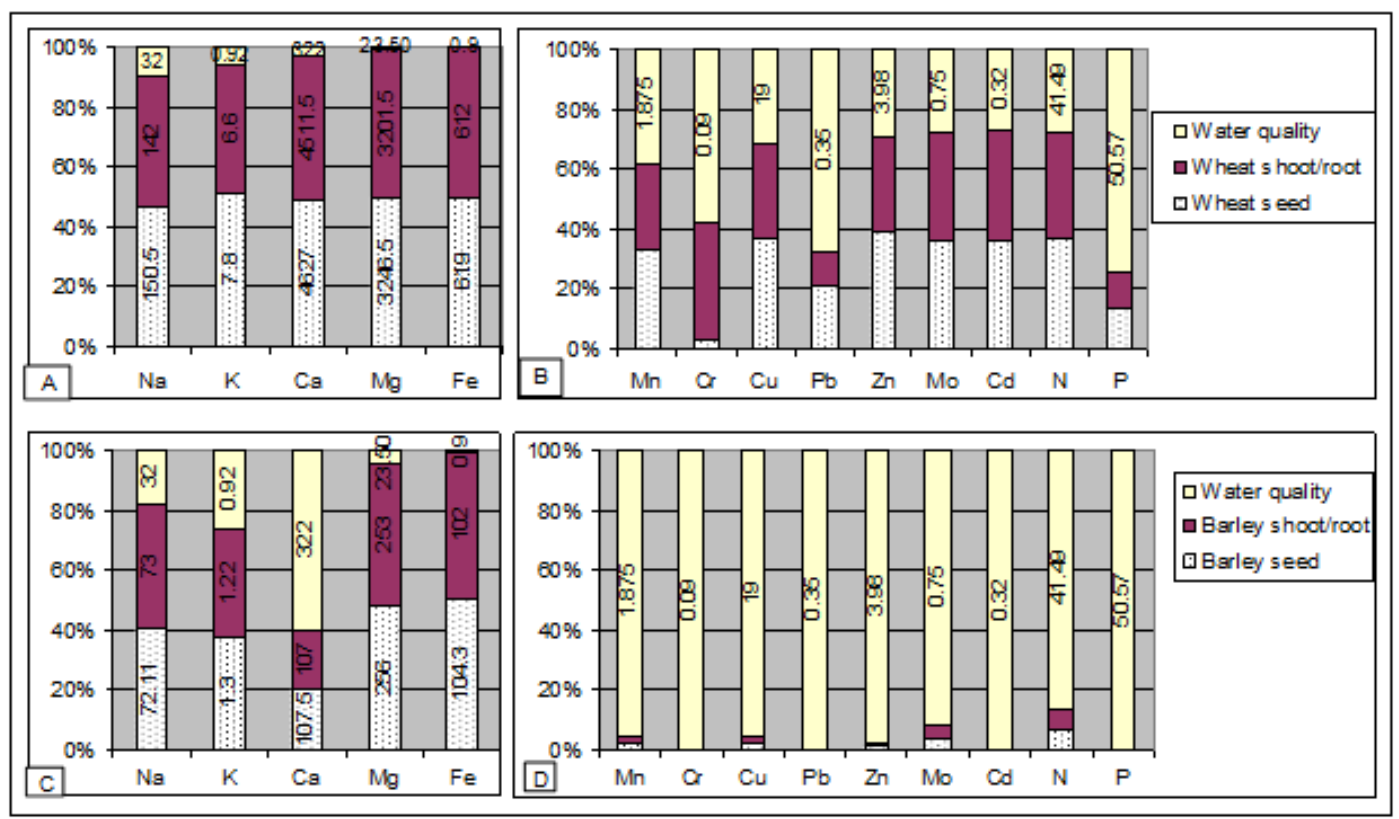

Figure 5. Nutrient transfer graphs for Major (A and B) in Wheat and Trace/Anion (C and D) in Barley parts (Note: $\mathrm{N}-\mathrm{NO}_{3} ; \mathrm{P}-\mathrm{PO}_{4}$ ).

The relative bar sizes help to understand the transfer of nutrients from shoot/root to seeds. Wheat has higher storability of all nutrients than Barley. Wheat seed stores more major nutrients in addition to some trace metals ( $\mathrm{Mn}, \mathrm{Cu}, \mathrm{Pb}$, and $\mathrm{Zn}$ ) than its shoot/root. Leandro et al. (2014) had indicated that the nutritional status of barely crops was not affected by gypsum application.

The factor analysis conducted summarizes the interrelationships in the nutrient distribution among the crop's parts, soil, gypsum powder and water. The factor analysis produced four factors with total variance of $93.3 \%$. The first factor accounting for $53.8 \%$ of the total variance contains $\mathrm{Mn}, \mathrm{Cu}, \mathrm{Zn}, \mathrm{Mo}, \mathrm{Cd}, \mathrm{Cd}, \mathrm{NO}_{3}$ and $\mathrm{PO}_{4}$. One-way ANOVA suggested that these Parameters may be associated with their accumulation within the Wheat seed, shoot and root. It can be noted that barley parts showed lesser nutrients accumulation as implied from the observation that its blend soil contain higher values of these nutrients. As one of its undesirable effects, gypsum hinders the uptake of zinc, magnesium, iron, copper, and phosphorus in plants, leading to nutrient deficiencies (El-Sayed, 2016; Michalovicz et al., 2014). The second factor has 
$\mathrm{Na}, \mathrm{K}, \mathrm{Mg}$ and Fe and is possibly attributed to leaching in the soil under the impact of gypsum. According to Elrashicli et al. (2010) addition of gypsum increase the solubility of $\mathrm{K}, \mathrm{Ca}$ and $\mathrm{Mg}$. The third factor comprising $\mathrm{Ca}, \mathrm{Mn}$ and $\mathrm{SO}_{4}$ can be directly linked with the gypsum powder chemistry. The last factor with $\mathrm{Cr}$ and $\mathrm{Pb}$ might be attributed to loadings from water used for watering the crops and was fetched from groundwater tap.

\section{CONCLUSIONS}

Accumulation of trace metals in the experimental pots is generally higher than the reference control. Barley was noted to be more resistant to nutrient intake, especially heavy metals, than the wheat crops. Generally, the present study suggested that there is a significance effect on nutrient intake of the crops was observed due to gypsum powder. Gypsum powder mix increased the major and trace metals as well as anion content in the soil and consequently in crop parts as compared with the Control. Though weak variation with increasing proportions of gypsum powder mix is noted, evidently direct loadings from the gypsum powder on soil and crop parts was observed in similar fashion in the three mixes. Such constituents as $\mathrm{Ca}, \mathrm{SO}_{4}, \mathrm{Mn}$ and $\mathrm{Pb}$ were added on to the soil from gypsum powder. The soil chemical analysis reveals higher $\mathrm{Mg}$, $\mathrm{Cu}, \mathrm{Mo}, \mathrm{Cd}, \mathrm{N}$ and $\mathrm{PO}_{4}$ content making the geogenic nature of soil to be responsible rather than the powder for such constituents' intakes by the crops. Both the soil and gypsum powder have equivalent $\mathrm{Fe}, \mathrm{K}, \mathrm{Zn}$ and $\mathrm{Cr}$ concentration in decreasing order implying that the original soil is also a contributor.

\section{RECOMMENDATIONS}

On spot investigation is recommended to assess the direct impact of the gypsum powder emitted over the soil and crops. The regional government especially the region's land use and environmental protection agency should follow the progress through continuous assessment and enforce the factory to reduce the Dust emitted to the environment. The factory should take the initiative to assess the impact or to co-operate similar investigations and should modify the old plant to minimize the dust emitted to the surrounding environment. Comprehensive and in-situ impact assessment is recommended for detail understanding of the positive as well as negative effects of the dust gypsum on soil and plants morphology and yield. 


\section{ACKNOWLEDGEMENTS}

Our appreciation goes to geochemical Laboratory of the school of Earth Science in Mekelle University for careful analysis of the samples.

\section{CONFLICT OF INTEREST}

No conflict of interests.

\section{REFERENCE}

Abate, E., Hussein, S., Laing, M \& Mengistu, F. 2013. Quantitative responses of Teff Eragrostistef (Zucc.) Trotter] and weeping love grass [Eragrostiscurvula (Schrad.) Nees] varieties to acid soil. Australian Journal of Crop Science, 7: 1854-1860

Benjamin, J. 2005. Wind Data Evaluation after 6 Months. Wind Energy Program TERNAEthiopia Deutsche Ge-sellschaft ftir Technische Zusammenarbeit (GTZ) gmbH DagHammarskjold-Weg, 1-5.

Bossellini, A., Russo, A., Fantozzi, P.L., Getaneh, A \& Solomon, T. 1997. The Mesozoic succession of the Mekelle outlier (Tigre Province, Ethiopia). Mem. Sci. Geol., 49: 95-116.

El-Sayed Omran, E. 2016. A simple model for rapid gypsum determination in arid soils Model. Earth Systems and Environment. 2: 185 (doi: 10.1007/s40808-016-0242-3).

Elrashicl, M. A., Lam', T W., Cathy, A. S., Ellis, C. B., Philip, J. S \& Richard, F. 2010. Effects of gypsum addition on solubility of nutrients in soil amended with peat soil science. Soil Science, 175(4): 62-72 (doi: 10.1097/SS.0b013e3181ddSId0).

Ekholm, P., Pasi, V., Elina, J., Mikko, K., Kirsti, L \& Liisa, P. 2012. Gypsum amendment of soils reduces phosphorus losses in an agricultural catchment. Agricultural and Food Science, 21: 279-291.

Gebrekidan, M and Samuel, Z. 2011. Concentration and health implication of heavy metals in drinking water from urban areas of Tigray Region, Northern Ethiopia. Momona Ethiopian Journal of Science, 3(1): 105-121.

Herrero, J., Artieda, O \& Weindorf, D.C. 2018. The determination of gypsum in soils. Soil Science Society of America Journal, 82: 293-294 (doi:10.2136/sssaj2017.12.0429). 
Khalil, A., Ghulam, Q., Abdul-Rehman, J., Amar, I. S., Qaisar, N. M., Muhammad, A. K \& Ehsan-Ul-Haq. 2017. Comparative reclamation efficiency of gypsum and sulfur for improvement of salt affected. Bulgarian Journal of Agricultural Science, 23 (1): 126-133.

Kost, D., Ken, J. L., Liming, C., Tom, M. D., Leo, E., Darrell, N. L., Dan, S. H., Allen, T., Dexter, B. W., Richard, P. W \& Warren, A. D. 2018. Meta-analysis of gypsum effects on crop yields and chemistry of soils, plant tissues, and vadose water at various research sites in the USA. J. Environmental Quality, 47: 1284-1292 (doi:10.2134/jeq2018.04.0163).

Leandro, M., Marcelo, M. L. M., José Salvador, S. F., Jackson, K., Ronaldo, N \& Luiz, F. M. K. 2014. Soil fertility, nutrition and yield of maize and barley with gypsum application on soil surface in no-till. R. Bras. Ci. Solo, 38: 1496-1505.

Mamedov A. I., Shainberg I., Wagner L. E., Warrington D. N \& Levy G. J. 2009. Infiltration and erosion in soils treated with dry PAM, of two molecular weights, and phosphogypsum. Australian Journal of Soil Research, 47: 788-795.

Mamun, A. A., Sarker, P. R \& Noor, M. M. A. 2019. Influence of irrigation and gypsum on wheat cultivation in saline soil. Research in Agriculture, Livestock and Fisheries, 6(1): 110.

Matula, J \& Pechová, M. 2007. The influence of gypsum treatment on the acquirement of nutrients from soils by barley. Plant Soil Environ., 53 (2): 89-96.

Marchesan, E., Felipe, T., Gustavo, M. T., Lucas, L. C., Bruno, B. A \& Vinicius, S. T. 2017. Soil management and application of agricultural gypsum in a Planosol for soybean cultivation. Crop Production, 47: 11 (http://dx.doi.org/10.1590/0103-8478cr20161102).

Qadir, M., Noble, A. D., Schubert, S., Thomas, R. J \& Arslan, A. 2006. Sodicity-induced land degradation and its sustainable management: problems and prospects. Land Degradation and Development, 17(6): 661-676.

Rodriguez-Navarro, A \& Rubio, F. 2006. High-affinity potassium and sodium transport systems in plants. Journal of Experimental Botany, 57: 1149-1160 (doi: 10.1093/jxb/erj068).

Vicensi, M., Müller, M.M.L., Kawakami, J., Nascimento, R., Michalovicz, L \& Lopes, C. 2016. Do rates and splitting of phosphogypsum applications influence the soil and annual crops in a no-tillage system? Rev Bras Cienc Solo. 40: 1-17 (https://doi.org/10.1590/ 18069657rbcs-20150155). 